\title{
Volcano collapse along the Aleutian Ridge (western Aleutian Arc)
}

\author{
C. Montanaro ${ }^{1}$ and J. Beget ${ }^{2}$ \\ ${ }^{1}$ University of Roma La Sapienza, Dip. Scienze della Terra, P.le Aldo Moro 5 Roma 00185, Italy \\ ${ }^{2}$ Department of Geology and Geophysics and Geophysical Institute, University of Alaska, Reichardt Building Room 308, \\ 900 Yukon Drive, Fairbanks, AK, 99775-5780, USA
}

Received: 14 July 2010 - Revised: 15 October 2010 - Accepted: 3 November 2010 - Published: 8 March 2011

\begin{abstract}
The Aleutian Ridge, in the western part of the Aleutian Arc, consists of a chain of volcanic islands perched atop the crest of a submarine ridge with most of the active Quaternary stratocones or caldera-like volcanoes being located on the northern margins of the Aleutian Islands. Integrated analysis of marine and terrestrial data resulted in the identification and characterization of 17 extensive submarine debris avalanche deposits from 11 volcanoes. Two morphological types of deposits are recognizable, elongate and lobate, with primary controls on the size and distribution of the volcanic debris being the volume and nature of material involved, proportion of fine grained material, depth of emplacement and the paleo-bathymetry. Volume calculations show the amount of material deposited in debris avalanches is as much as three times larger than the amount of material initially involved in the collapse, suggesting the incorporation of large amounts of submarine material during transport. The orientation of the collapse events is influenced by regional fault systems underling the volcanoes. The western Aleutian Arc has a significant tsunamigenic potential and communities within the Aleutian Islands and surrounding areas of the North Pacific as well as shipping and fishing fleets that cross the North Pacific may be at risk during future eruptions in this area.
\end{abstract}

\section{Introduction}

Island volcanoes sometimes undergo huge sector collapses generating submarine volcanic landslides and giant debris avalanches that can travel for tens of kilometers across the sea floor. Prior studies have identified multiple giant submarine landslide deposits surrounding volcanic islands associ-

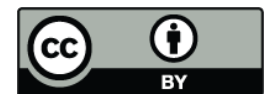

Correspondence to: C. Montanaro (cristianmontanaro@libero.it) ated with hot spot volcanism, such as the Hawaiian Islands (Moore et al., 1989, 1994), Azores Islands (Holcomb and Searle, 1991), Canary Islands (Watts et al., 1995; Masson et al., 2002), Cape Verde Islands (Le Bas et al., 2007; Masson et al., 2008) and Society Islands (Clouard et al., 2001). Similar deposits have been found around volcanic islands and island arcs above subduction zones, including volcanoes in the Lesser Antilles Arc (Boudon et al., 2007), Japanese Arc (Satake and Kato, 2001), Tonga-Kermadec Arc (Wright et al., 2006), Bismark Island (Silver et al., 2009), Aeolian Island (Tibaldi, 2001; Romagnoli et al., 2009) and the Aleutian Island Arc (Coombs et al., 2007b).

The recurrence of such events today could generate huge tsunamis that would cause damage and destruction at coastal facilities and loss of life in coastal communities (Beget, 2000; Ward and Day, 2003). The aim of this paper is to enhance our knowledge concerning debris avalanches that have occurred along the Aleutian Arc in westernmost Alaska (Fig. 1). We present here the results of a new integrated study of both terrestrial and submarine imagery for the Aleutian Ridge. We utilized multibeam and side-scan sonar data for a large region offshore from the western Aleutian Islands and the major volcanoes of the Aleutian Ridge. The swath bathymetry and side-scan data reveal a number of debris avalanche (hereafter DA) deposits; we describe each of these and discuss their volcanic and tectonic settings. As in the Coombs et al. (2007b) paper we merged the submarine data with digital topography obtained from the Space Shuttle laser altimetry program in order to make a complete quantitative analyses of both the source areas and the submarine deposits of multiple Aleutian Island DAs. In some areas the only submarine data available is quite old (1930-1980s) and has low resolution or only incompletely covers the study area. In these areas we can still identify DA deposits, but without new high resolution imagery we cannot determine whether more than one deposit is present. 


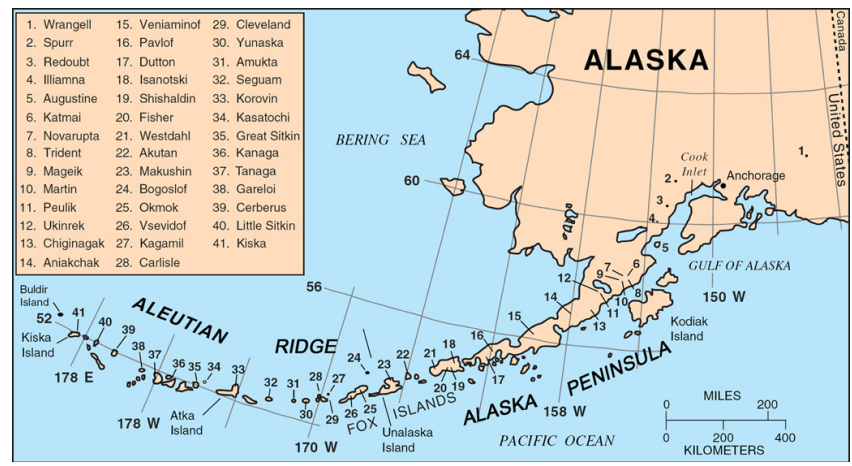

Fig. 1. Location of Aleutian Ridge with respect to the Aleutian arc. Most of the volcanoes in the list have erupted in the last 200 years.

We report here on 7 submarine DAs originating from the volcanoes of the Rat Islands (Kiska, Segula and Little Sitkin), 10 submarine DAs from the Andreanof Islands (Gareloi, Tanaga, Bobrof, Kanaga, Adak, Great Sitkin and Seguam) group and a single subaerial collapse feature recognized at Recheshnoi Island.

Two distinct types of DAs were differentiated on the basis of their morphology and source areas: elongate deposits typically extended into deep water tens of kilometers downslope from the source area and were formed by voluminous collapses from volcanoes composed of lava flows and interbedded pyroclastic material, while less extensive and dominantly lobate deposits were produced by smaller collapses into shallow water from edifices composed mainly of lava flows.

Once the location and extent of the submarine DAs and their relationship to source volcanoes was determined, we evaluated the regional tectonic setting of the volcanoes to look for possible relationships between fault systems underlying the volcanoes and the orientation and preferred failure directions of the subaerial volcanic landslide scarps.

Finally we estimated the potential height of potential tsunami waves that might be generated by similar volcanic edifice collapses today to evaluate the risk such events might present for coastal communities within the Aleutian Islands, at sites around the margins of the North Pacific Ocean, and to fishing fleets in the Aleutian Islands and ships travelling the North Pacific shipping routes between Asia and North America.

\section{Regional setting}

The Aleutian Arc is a 2500-km-long subduction-related island arc, and consists of two geologically distinct segments that meet at Unimak Pass: the Aleutian Ridge on the west and the Alaska Peninsula on the east (Fig. 1). The arc is being underthrust at about $90^{\circ}$ by the Pacific plate in the eastern part at rates of about $7.5 \mathrm{~cm} /$ year, whereas in the far western part the North American Plate and Pacific Plate motions be-

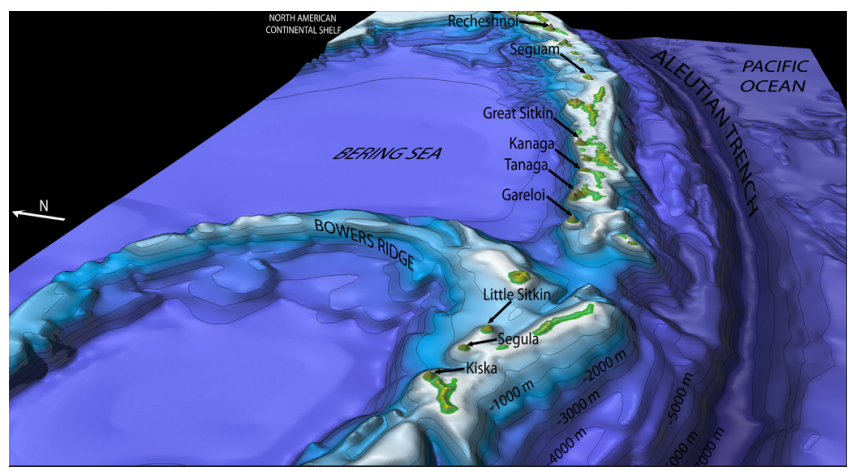

Fig. 2. 3-D view of the central Aleutian Ridge; it is clear how many of the stratocone volcanoes are located along the steepest north edge.

come nearly parallel and subduction rates decline to about $2.5 \mathrm{~cm} /$ year (Grow and Atwater, 1970; DeLong et al., 1978; Engebretson et al., 1985).

The Aleutian Ridge is a composite feature made up of a chain of volcanic islands perched atop the crest of a huge submarine ridge that has been fragmented into a series of discrete fault-bounded blocks, each block being tens to hundreds of kilometers in length (Geist et al., 1988). The individual volcanic islands are constructed on the fault-bounded blocks and formed as large tholeiitic volcanoes and smaller andesitic cones (Kay et al., 1982) constructed on mildly metamorphosed to virtually unaltered late Tertiary volcanic units. Almost all of the most important Quaternary volcanic centers are located on the northern side of the arc.

Volcanic activity along the arc began during the middle Eocene (about $46 \mathrm{Ma}$ ) and has continued intermittently up to the present day (Jicha et al., 2006). At least 40 volcanoes have erupted in the past 250 years and another 20 volcanoes have been active in the Holocene (Simkin and Siebert, 1994; Miller et al., 1998; Schaefer and Nye , 2002).

The geologic history and modern geodynamic setting of the Aleutian Ridge have produced a chain of volcanic islands that is bordered on the north by a steep slope descending to the Bering basin, the deepest part of which is about $3800 \mathrm{~m}$ below sea level, while the remnants of older volcanic arcs and related Tertiary volcaniclastic deposits occur to the south of the islands. This results in a significant asymmetry of the underwater slopes which average about $10-15^{\circ}$ to the north, and only $2-3^{\circ}$ to the south around the Aleutian Islands (Fig. 2). An exception is the Kiska-Little Sitkin and Segula sector where the Aleutian Ridge is characterized by two submarine steps; the first-one immediately offshore drops down to a depth range of 300-1000 m b.s.l., and the second one about $30-50 \mathrm{~km}$ to the north drops from about $1800 \mathrm{~m}$ b.s.l. to the abyssal sea floor of the Bering Sea at about $3800 \mathrm{~m}$ b.s.l. (Fig. 2). 


\section{Data and methods}

The subaerial geology of the Aleutian Islands has been studied by US Geological Survey (USGS) scientists in the 1960s (Coats, 1956b, 1959c; Coats et al., 1961; Snyder, 1957, 1959; Simons and Mathewson, 1955; Nelson, 1959) and by scientists from the USGS and the Alaska Volcano Observatory (AVO) from the 1990s until now. Several important works on edifice collapse and submarine DAs at Gareloi, Tanaga, Kanaga and Great Sitkin have recently been published (Waythomas et al., 2002, 2003a,b,c; Coombs et al., 2007a,b, 2008).

As part of this study, adopting the same approach of Coombs et al. (2007b), we made the analyses of the subaerial morphology of the source volcanoes using remotely sensed data collected during the Shuttle Radar Topography Mission (SRTM) available from the USGS Seamless Data Distribution System. We used the SRTM data set to construct DEMs of the entire western Aleutian arc study area with 1 arc second $(30 \mathrm{~m})$ resolution.

In addition, new analyses of seafloor bathymetry were made using data from the National Geophysical Data Center (NGDC), including the Hydrographic Survey Data (NOS) supplemented by medium-high resolution (50-10 $\mathrm{m}$ ) bathymetric data generated from the NGDC Autochart Bathymetric Map Production system. In addition the same dataset of localized high resolution ship-based bathymetry used by Coombs et al. (2007b) for the Kiska and Gareloi volcanoes was obtained and integrated into the bathymetric models. In many cases the bathymetric data did not have high enough accuracy or resolution or did not extend deep into the Bering Sea, so in order to define the boundaries and features of the deposits for the mapped landslide we integrated our new digital bathymetric with the GLORIA-data acquired in Bering Sea and North Pacific seafloor around the west-central Aleutians during 1986 and 1987 surveys (EEZ Staff, 1991). The Gloria dataset is only capable of resolving seafloor features larger than several hundred meters, limiting our ability to precisely determine the margins of the some of the most extensive submarine DAs.

\section{New mapping of subaerial edifice failures and subma- rine debris-avalanche deposits}

A morphological analysis of volcanoes that had produced DAs, made using our subaerial edifice DEM, allowed us to define the spatial and temporal evolution of the collapse events by mapping the intersection, erosion and continuity of amphitheatre structure (visible or inferred). For volcanoes where the landslide included a submarine component, we used multibeam and side scan data to recognize large debris fields and morphological bulges with scattered blocks, expressions of thick deposits that can be associated with the on-land blocks and deposits of the DAs.
The DA deposits vary in shape from elongate to lobate, contain blocks of various sizes, including some as much as $1000 \mathrm{~m}$ across and extend down-slope from the source volcanoes and tend to become progressively wider with distance from the source. The elongate DA deposits are typically characterized by the presence of a large debris field in the proximal-mid distance, ca. $10-45 \mathrm{~km}$ from the source vents, with elongate blocks and trains of blocks usually aligned along the direction of the probable original flow, and by a slightly more distal zone characterized by fewer scattered blocks and finer matrix material (as suggested by backscatter information). The lobate deposits mainly consist of large blocks randomly distributed through the entire submarine area of the deposit.

A common feature is the presence of downslope channels bounded by steep and linear ridges that are aligned with the outer limits of the horseshoe-shaped collapse scarps of the subaerial edifice; we infer that these slide regions might have contributed in many cases to the DA material by incorporation of submarine substrate during transport.

In a few regions conical structures are present that are significantly larger than the largest blocks in nearby DA deposits, and appear to be older volcanic cones that predate the DA deposits described in this report (Reynolds et al., 2004).

The principal characteristics of the scarps produced by edifice collapse and the associated submarine DA deposits are summarized below (Table 1).

\subsection{Kiska}

The Holocene stratocone of Kiska, which most recently erupted in 1990 (Miller et al., 1998), is the westernmost historically active volcano in the Aleutian arc. The subaerial volcanic cone morphology exposes multiple fault planes and collapse scarps providing evidence for multiple episodes of edifice failure on the NNW, NNE and SE sides (Fig. 3). The NNE-directed collapse scar is cut by a younger NNWdirected scar that in turn has been completely filled in by later growth of the volcano. A third collapse scar on the southeast side of the volcano is the most recent, as demonstrated by the fresh morphology and by its incision of the second scar (Fig. 3).

On the NNE side of Kiska, downslope from a collapse scar, there is a hummocky area covering $165 \mathrm{~km}^{2}$ that defines an extensive submarine DA deposit (Fig. 3). In side-scan imagery a high-backscatter signal characterizes the main part of the deposit, which contains scattered blocks as much as $400 \mathrm{~m}$ in diameter and is incised by several channels. Downslope from the high-backscatter area is a lower back-scatter region with a more subdued hummocky surface. These characteristics suggest that this region is an older DA deposit that is partly buried by post-emplacement deposits of marine sediments. Unfortunately, we do not have high-resolution multibeam data in this area to better constrain these observations. A broad erosive channel cuts the slope in front of 


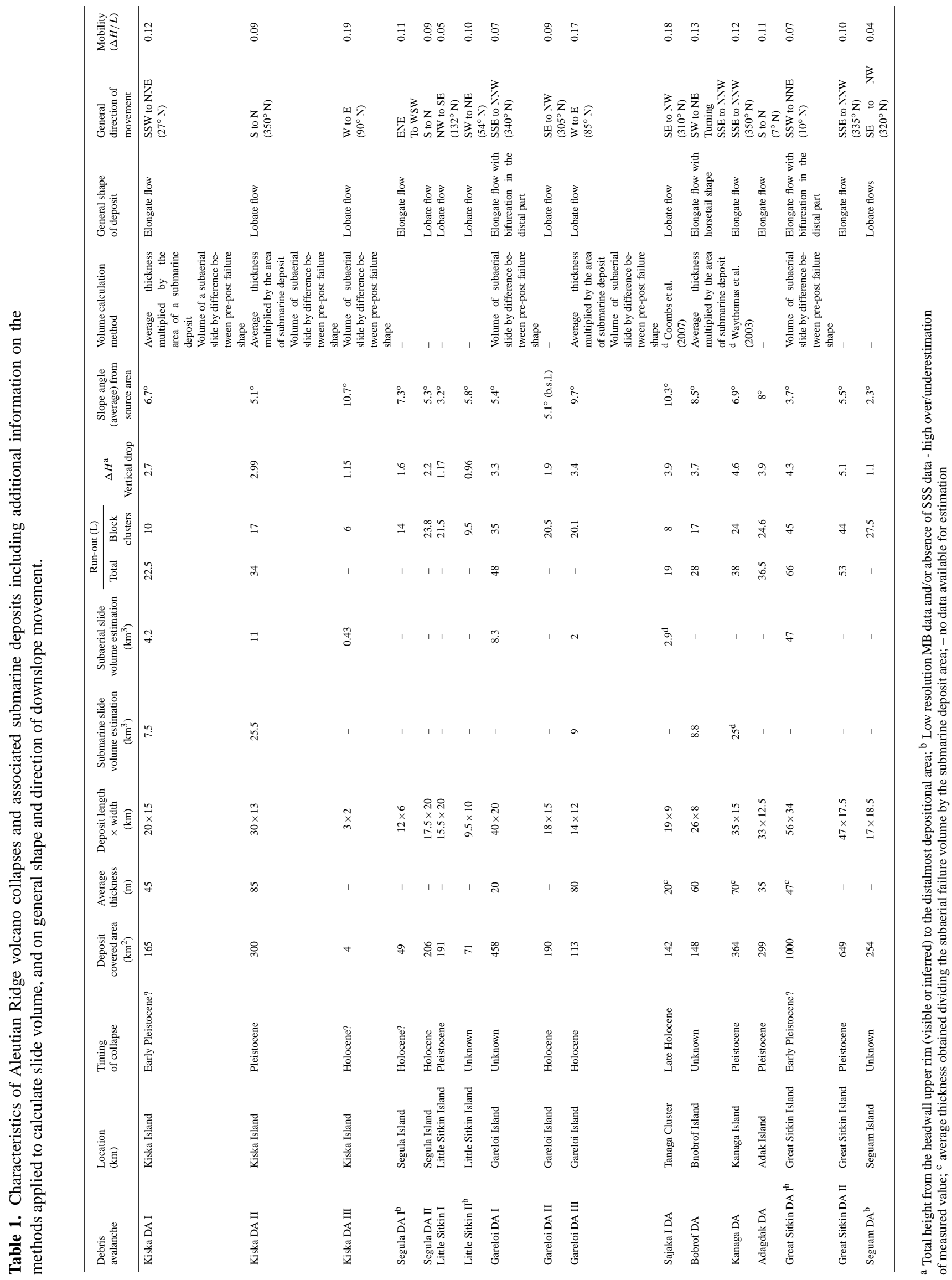




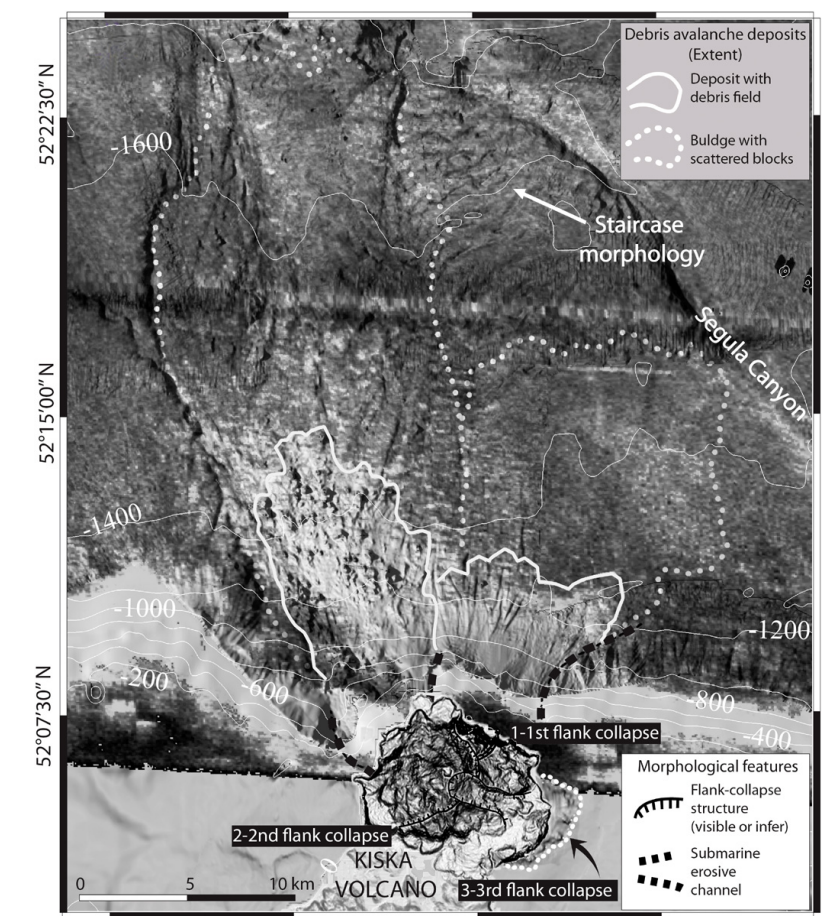

(a)

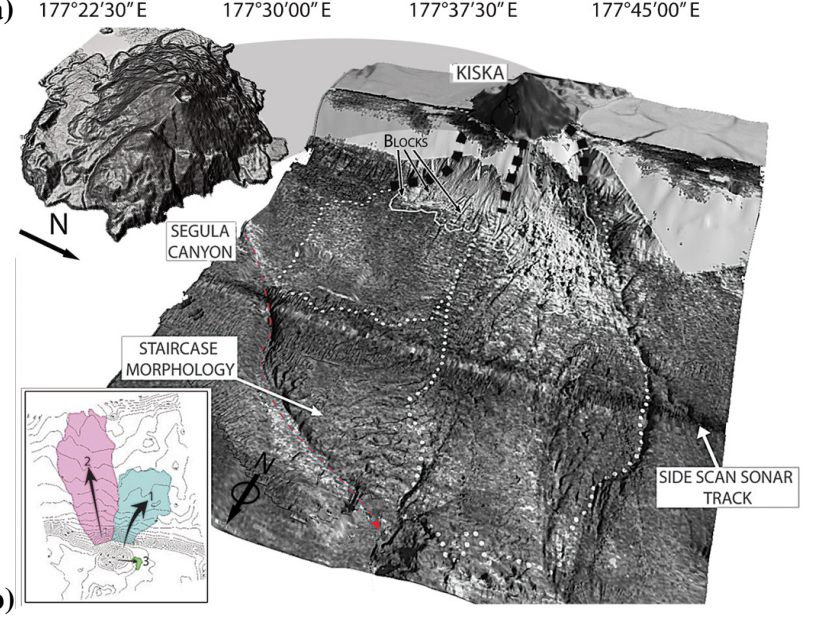

Fig. 3. (a) plan view: topography, bathymetry and Gloria side-scan data of Kiska volcano and its northern submarine slopes. (b) 3-D view: is reported also a detailed view of the subaerial volcanic cone morphology exposing fault planes and collapse craters. For side scan data the black is low backscatter and white is high backscatter. Contour interval is $200 \mathrm{~m}$.

this deposit, and may record erosion by submarine currents diverted around the topographically high debris deposits (Fig. 3).

In the area NNW of Kiska downslope from the second collapse scar, a field of large blocks can be seen in both the bathymetry and the side-scan imagery (Coombs et al., 2007b). This concentration of large blocks extends $13 \mathrm{~km}$ offshore, and together with a more distal scattered block field found up to more than $30 \mathrm{~km}$ from the island, indicates this DA deposit covered an area of $300 \mathrm{~km}^{2}$.
The largest blocks visible in the imagery range from $250 \times$ $200 \times 15 \mathrm{~m}$ to $750 \times 450 \times 90 \mathrm{~m}$ in size. A higher-backscatter region with respect to the surrounding seafloor is visible at the base of the second submarine step (see above) just beyond the scattered block field and is interpreted as a distal facies of the DA deposit that traveled to the deepest part of the basin.

These two DA deposits are located within a bathymetric low, bordered by the 100-180 m deep submarine Segula canyon on the east side and a 50-120 m high step in the slope on its western side. In addition, a zone of contour-parallel steps $4.5-7 \mathrm{~km}$ wide, separated by troughs 20 to $60 \mathrm{~m}$ deep, is present in front of the oldest DA deposit at a distance of 15 to $28 \mathrm{~km}$ offshore (Fig. 3b). Coombs et al. (2007b) suggest that these forms are coarse sediment waves formed by turbidite events due to the similarity with the forms observed offshore of Maui Island (Eakins and Robinson, 2006). This morphology is also similar to open linear/arcuate creep-like fold crests and staircase successions indicating areas prone to, or that have experienced further destabilization and levelling following a large scale slope failure event (Canals et al., 2004). In this case the contour parallel steps may be due to sudden loading of the unconsolidated basinal sediments by the arrival of the DA deposit.

A third collapse generated a small DA, which covered an area of $4 \mathrm{~km}^{2}$, directly on the shallow platform at the crest of the Aleutian Ridge. In this case a region of hummocky terrain that in its southern part overrides the remains of the oldest cone can be recognized, but the low resolution of the data does not allow any more detailed information to be obtained (Fig. 3a).

\subsection{Segula}

On the NNE and SSW side of the subaerial stratocone of Segula two collapse scars were recognized, with an older scar being cut by a younger one (Fig. 4). Field evidence has been reported of a DA deposit on Segula Island formed by the most recent collapse event (Nelson, 1959, p. 264). Consistent with Coombs et al. (2007b) we recognized a hummocky area covering about $200 \mathrm{~km}^{2}$ corresponding to the continuation of this DA on the seafloor north of Segula (Fig. 4). The deposit, seen in GLORIA images, has a lobate shape and reaches a distance of about $20 \mathrm{~km}$ from the volcano. A single highresolution swath that covers the middle part of the deposits confirms the presence of multiple huge landslide blocks, with the largest one reaching $700 \mathrm{~m}$ in diameter and standing more than $100 \mathrm{~m}$ higher than the surround matrix of the landslide deposit (Fig. 4).

On the south within the Segula channel we identified a second presumed DA deposit facing the older collapse scar. This DA was probably re-directed by the margins of the channel so it traveled dominantly in the down-slope direction; the available data show some hummocky features that were previously attributed to a submarine cone by Snyder (1957) and 


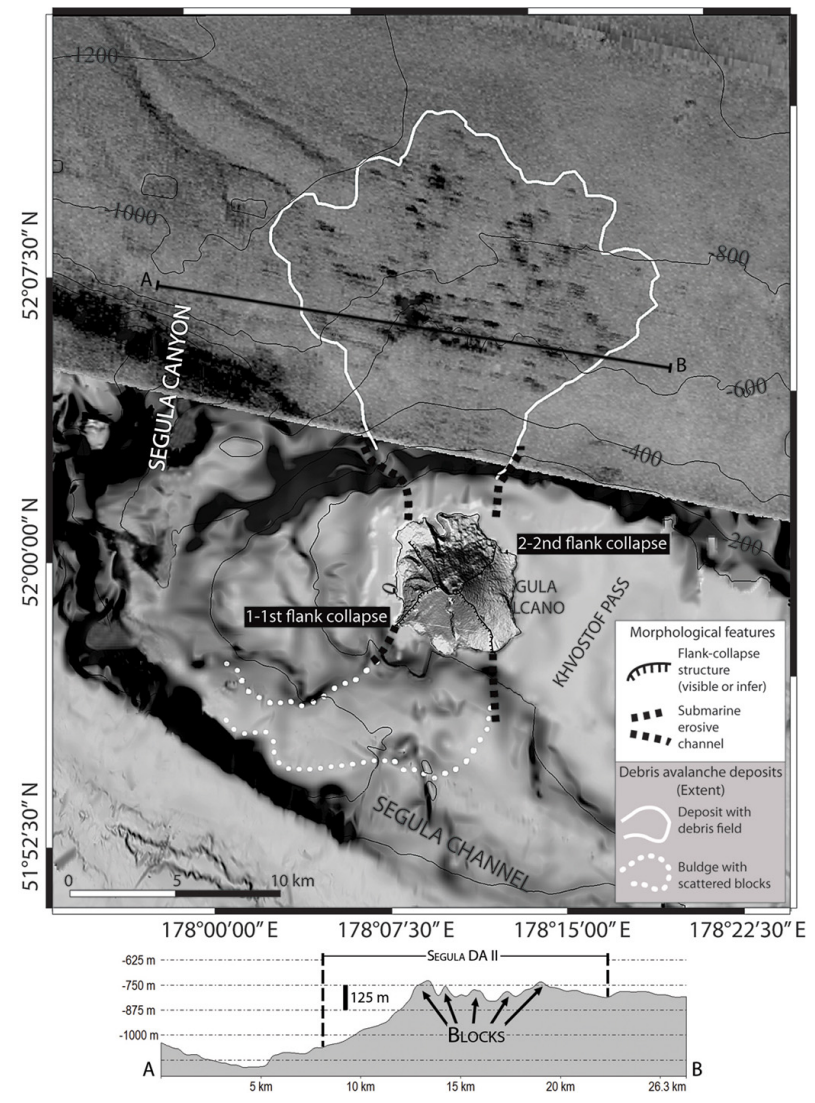

Fig. 4. Topography, bathymetry and Gloria side-scan data of Segula volcano and its northern submarine slopes. A transversal profile is reported showing the lenticular shape of the deposit and the presence of large blocks. The image displays the speckled pattern characteristic of large debris slide deposits on the north side. For side scan data the black is high backscatter and white is low backscatter. Contour interval is $200 \mathrm{~m}$.

that we reinterpret as DA hummocks based on their shape and distribution.

\subsection{Little Sitkin}

Little Sitkin is a volcanic island with an active stratovolcano occurring within the eroded remnants of a nested double caldera of probable late Pleistocene age (i.e. Caldera One and Caldera Two of Snyder, 1959).

On the SE side of the island we identified a hummock field with a lobate shape that covers an area of about $190 \mathrm{~km}^{2}$ (Fig. 5). Side scan data reveal a distinctive partly speckled pattern with low reflectivity suggesting a buried landslide deposit. The debris field extends approximately $17 \mathrm{~km}$ offshore, and originates at a horseshoe-shaped scar that cut the Caldera One rim (Fig. 5). Part of this feature was attributed by Snyder (1959) to the Caldera Two event, but the presence of this debris field suggests that this feature was probably formed when a collapse event occurred. Recent surveys on

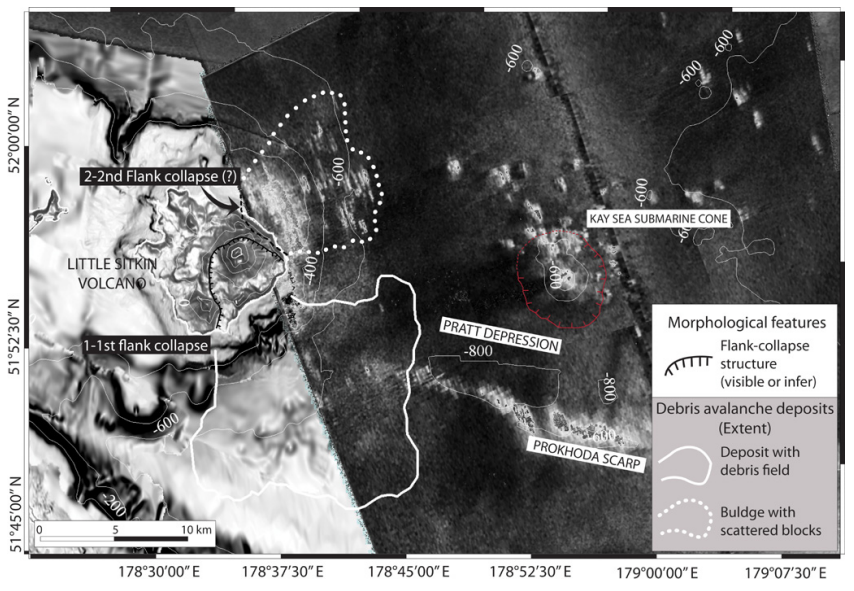

Fig. 5. Topography, bathymetry and Gloria side-scan data of Little Sitkin island. The image displays large debris slide deposits around the island and Kay Sea submarine cone (Snyder, 1957). For side scan data the black is high backscatter and white is low backscatter. Contour interval is $200 \mathrm{~m}$.

the island confirm the presence of DA deposits inside the inferred source area (J. Larsen, personal communication), and support our interpretation of the submarine deposits as that of a large DA.

The NE-part of the island abuts the sea in a huge cliff standing over $500 \mathrm{~m}$ high; in the submarine area facing this cliff, another field of large blocks can be seen in the sidescan imagery (Fig. 5). The blocks are found more than $8 \mathrm{~km}$ offshore and cover an area of approximately $70 \mathrm{~km}^{2}$. Thus the NE facing cliff is interpreted as the scarp left behind by this large DA. Unfortunately, no high-resolution bathymetry of the seafloor is available in this area, but the steepness and fresh appearance of the subaerial scarp suggests this event may be relatively recent in age.

\subsection{Gareloi}

Gareloi Volcano appears to have been the source of multiple discrete collapse events. A small collapse scar is visible on the modern cone, and three large submarine DAs occur on the N, NW, and E sides of Gareloi Island (Coombs et al., 2007b). The backscatter and multi-beam data shows a submarine source area for the NW deposit consisting of a continuous $6.5 \mathrm{~km}$ wide headwall scarp ranging from 150 to $200 \mathrm{~m}$ in height, cut along the platform and located at a distance of $0.5-2.5 \mathrm{~km} \mathrm{NW}$ (seaward) from the modern shoreline (Fig. 6). This feature is one of the best developed submarine scarps left by a completely subaqueous landside anywhere in the Aleutian Islands, and clearly shows the importance of integrating subaerial and submarine data sets evaluating histories of landslide collapse at volcanic islands.

Moreover, our results show, at a distance of about $26 \mathrm{~km}$ $\mathrm{N}-\mathrm{NW}$ from Gareloi, the presence of arcuate crests and staircase morphologies that suggest continued submarine 


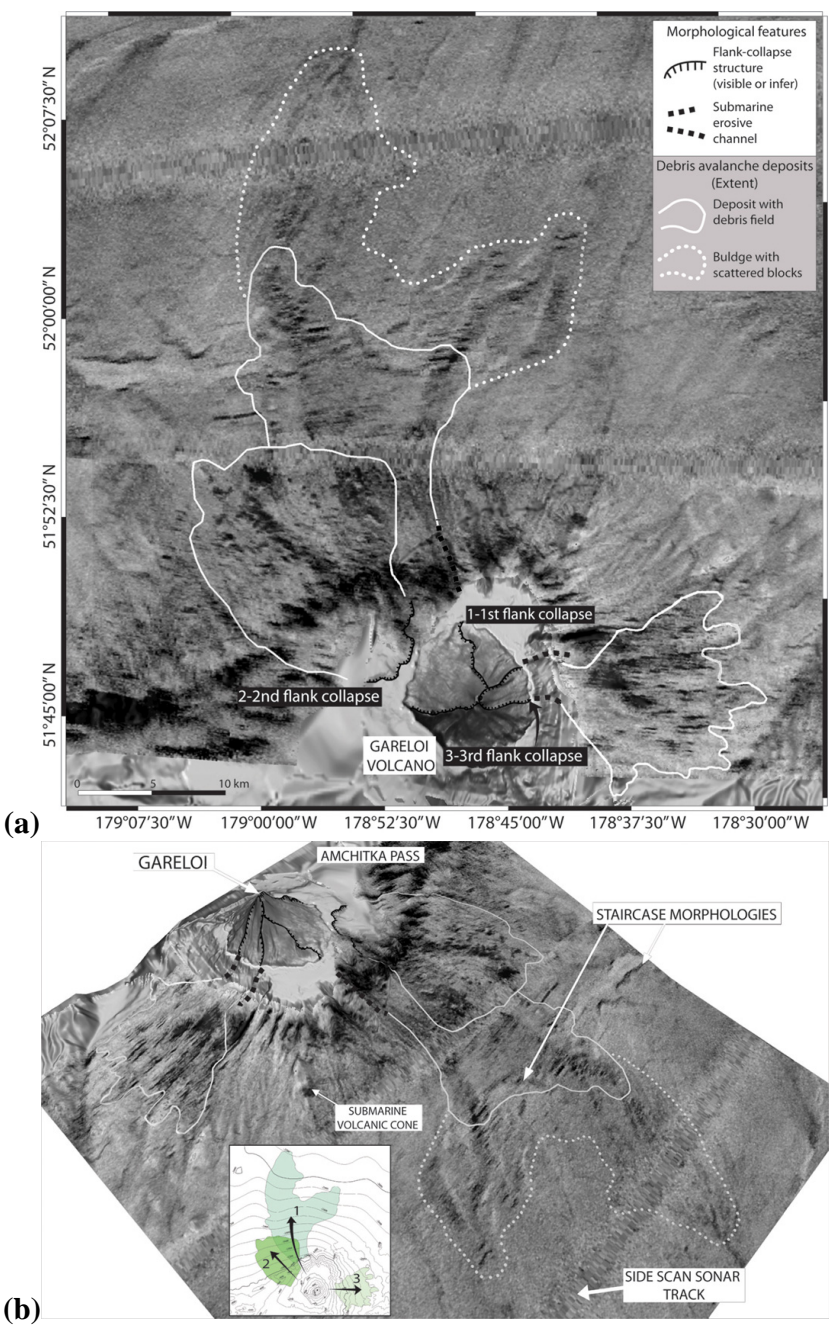

Fig. 6. (a) Plan view: topography, bathymetry and Gloria side-scan data of Gareloi island. The image displays the three deposits surrounding the volcano. Also visible are arcuate crests and staircase morphologies on the NNW. (b) 3-D view. For side scan data the black is high backscatter and white is low backscatter.

instability conditions in this area. Some of these features seem to intersect and cut across part of the Northerly direct DA, suggesting they have been active relatively recently (Fig. 6).

\subsection{Tanaga}

Tanaga Island covers $529 \mathrm{~km}^{2}$ and at least three discrete Quaternary volcanic centers occur on its northern half. From west to east the volcanoes are named Sajaka, Tanaga, and Takawangha (Fig. 7). The first two centers are steep-sided cones of Holocene age whereas the latter is a PleistoceneHolocene volcano build on a 300-m-thick sequence of Pleistocene and older volcanic and volcaniclastic rocks (Coombs et al., 2007a,b). Two morphological features record collapse events that affected each of these volcanoes.
A wide scarp on Tanaga Island separates the Takawangha and Tanaga volcanic edifices and can be traced into submarine scarps on both the north and south flanks of the island (Fig. 7). This feature appears to have formed when the northwest portion of Tanaga Island collapsed into the sea (Coombs et al., 2007a,b), and the scale and the arcuate shape of the scarp suggests that it was the source of huge compound slides. Some hummocky features are visible in the proximal part of the deposit but the age of the largest Tanaga collapse (>140 ka; Coombs et al., 2007a,b), as well has the low reflectivity suggest this deposit is largely buried by marine sediments.

An intermediate age-collapse occurred from the west side of Sajaka volcano where an earlier edifice, called Sajaka I, was truncated and cut nearly in a half, before a new, younger cone (Sajaka II) formed in the scar (Coombs et al., 2007a,b). Our mapping of the resulting DA deposit shows that it covered an area of $200 \mathrm{~km}^{2}$ with an elongate shape and a zone with sparse blocks in the proximal area (Fig. 7). Also, several small submarine volcanic cones are present in this area (Reynolds et al., 2004) with at least one of them partially buried by the DA (Fig. 7).

\subsection{Bobrof}

Bobrof island, located east of Tanaga island, is a youngappearing stratovolcano, but little is known about its eruption history or geology (Wood and Kienle, 1991).

The submarine base of the volcanic edifice is perched on a symmetrical and elongated N-S trending ridge. The volcano is located on the southern part of the ridge and is bordered on the north by a shallow-water platform, while to the south a saddle connects Bobrof with the summit plateau of the main part of the Aleutian Ridge (Fig. 8).

A collapse scar, mostly filled in by later volcanic products, is situated on the east side of the cone. Just downslope from this feature is a DA deposit with a horsetail shape. A block field is present in the SW-NE portion of this deposit while a smoother-appearing deposit with isolated blocks partially overlaps the Kanaga deposit in an SSE-NNW direction (Fig. 8). The proximal part of the deposit is scoured by an active canyon that begins in shallow water about $1.5 \mathrm{~km}$ from the shoreline and continues down to $2200 \mathrm{~m}$ depth (Fig. 8).

\subsection{Kanaga}

Kanaga Volcano is a Holocene andesitic stratovolcano bounded on its southern margin by the Kanaton Ridge. This major topographic feature was formed as the result of a northward-directed flank collapse that destroyed an ancestral volcano named Mount Kanaton (Waythomas et al., 2002, 2003a,c).

In agreement with previous work (Waythomas et al., 2003a,c; Coombs et al., 2007b) we recognized a DA deposit on the north side of Kanaga volcano where the Kanaton 


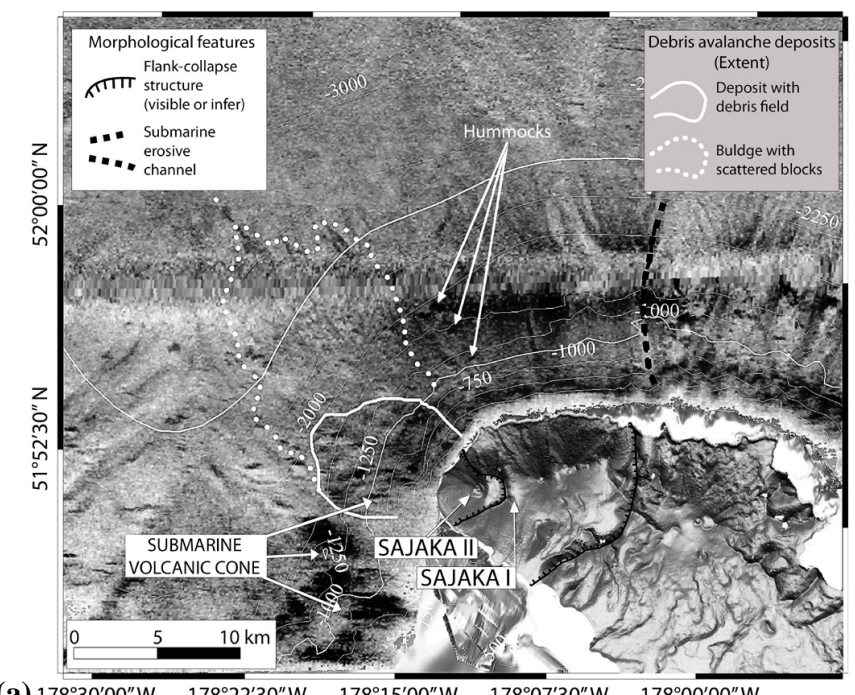

(a) $178^{\circ} 30^{\prime} 00^{\prime \prime} \mathrm{W} \quad 178^{\circ} 22^{\prime} 30^{\prime \prime} \mathrm{W} \quad 178^{\circ} 15^{\prime} 00^{\prime \prime} \mathrm{W} \quad 178^{\circ} 07^{\prime} 30^{\prime \prime} \mathrm{W} \quad 178^{\circ} 00^{\prime} 00^{\prime \prime} \mathrm{W}$

(b)

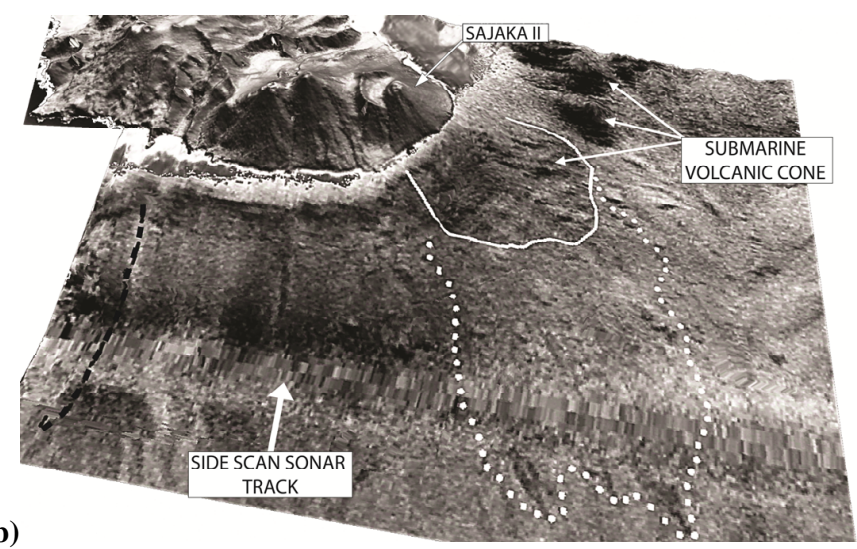

Fig. 7. (a) Plan view: topography, bathymetry and Gloria side-scan data of northern Tanaga cluster islands. (b) 3-D view: is reported a detailed view of the Sajaka II DA deposits. For side scan data the black is low backscatter and white is high backscatter. Contour interval is $250 \mathrm{~m}$.

horseshoe-shaped structure extends offshore associated with a $4.5 \mathrm{~km}$ wide, $50-200 \mathrm{~m}$ deep channel descending from sea level to $1100 \mathrm{~m}$ b.s.l. (Fig. 8).

The mapped DA deposit covers about $360 \mathrm{~km}^{2}$ and is elongate in the SSE-NNW direction. There is a block field concentrated in the mid-slope part of the deposit. The east side of the DA deposit is scoured by an active canyon that goes down to $2100 \mathrm{~m}$ b.s.l. and probably channels volcaniclastic deposits and sediment gravity flows fed by eruptive activity at Kanaga Volcanic.

\subsection{Adagdak}

Mount Adagdak is a volcano whose basal part consists of a broad shield composed mainly of basaltic lava which is overlain by the products of two younger composite cones (Coats, 1956b).

We recognize two separate collapse scars at Mr. Adagdak, an older one that cuts into the older cone and a second younger one on the younger cone that is clearly associated with a fresh-appearing DA deposit that can be mapped over an area of about $300 \mathrm{~km}^{2}$. The DA deposit has an elongate shape and numerous blocks found are clearly visible in the multibeam data at the base of the slope below the volcano. The medium-distal parts of this deposit exhibit few scattered blocks and some waveform features (Fig. 9).

The side-scan imagery of the debris field is characterized by a low reflectivity that suggests it has been buried by sediment transport down the numerous channels that are visible on the slope descending from the volcano.

Two erosive channels, 2.5 and $0.6 \mathrm{~km}$ in width respectively, were observed in front of each of the two scars; the first and larger one is best developed between 0 and $1300 \mathrm{~m}$ b.s.l. and is as much as 50-350 m deep (Fig. 9).

\subsection{Great Sitkin}

Great Sitkin Volcano is a Quaternary andesitic stratocone whose edifice is composed of a series of lava flows and lava domes that form an arcuate-shaped structure open to the northwest. The arcuate feature truncates a series of lava flows on the northeast side of the island and is a subdued headscarp that was formed during edifice collapse (Waythomas et al., 2003c).

The southern part of Great Sitkin consists of two groups of ancient volcanic rocks, the Finger Bay greenstones (Eocene in age) and the undeformed Sand Bay unit (late Tertiary), both underlings the modern edifice (Simons and Mathewson, 1955). This latter unit is the remnant of a now-vanished shield volcano whose summit was located near that of the modern cone (Simons and Mathewson, 1955).

North of Great Sitkin an area with large hummocks (some exceeding $1 \mathrm{~km}$ in length) is recognizable on side-scan data; Waythomas et al. (2003c) and Coombs et al. (2007b) have interpreted this as a DA deposit produced by a single enormous episode of edifice collapse. However, our mapping shows that this deposit was created by at least two separate collapse events. Our new interpretation is based on the presence of two differently aligned sets of blocks which allow the differentiation of two distinct units (Fig. 10). The youngest deposit covers about $650 \mathrm{~km}^{2}$ and shows a pronounced SSE-NNW alignment of the blocks. This deposit forms a fan-shaped debris field that can be traced back to the subdued headscarp that is the result of the edifice collapse event at Great Sitkin Volcano described by Waythomas et al. (2003c). An older 


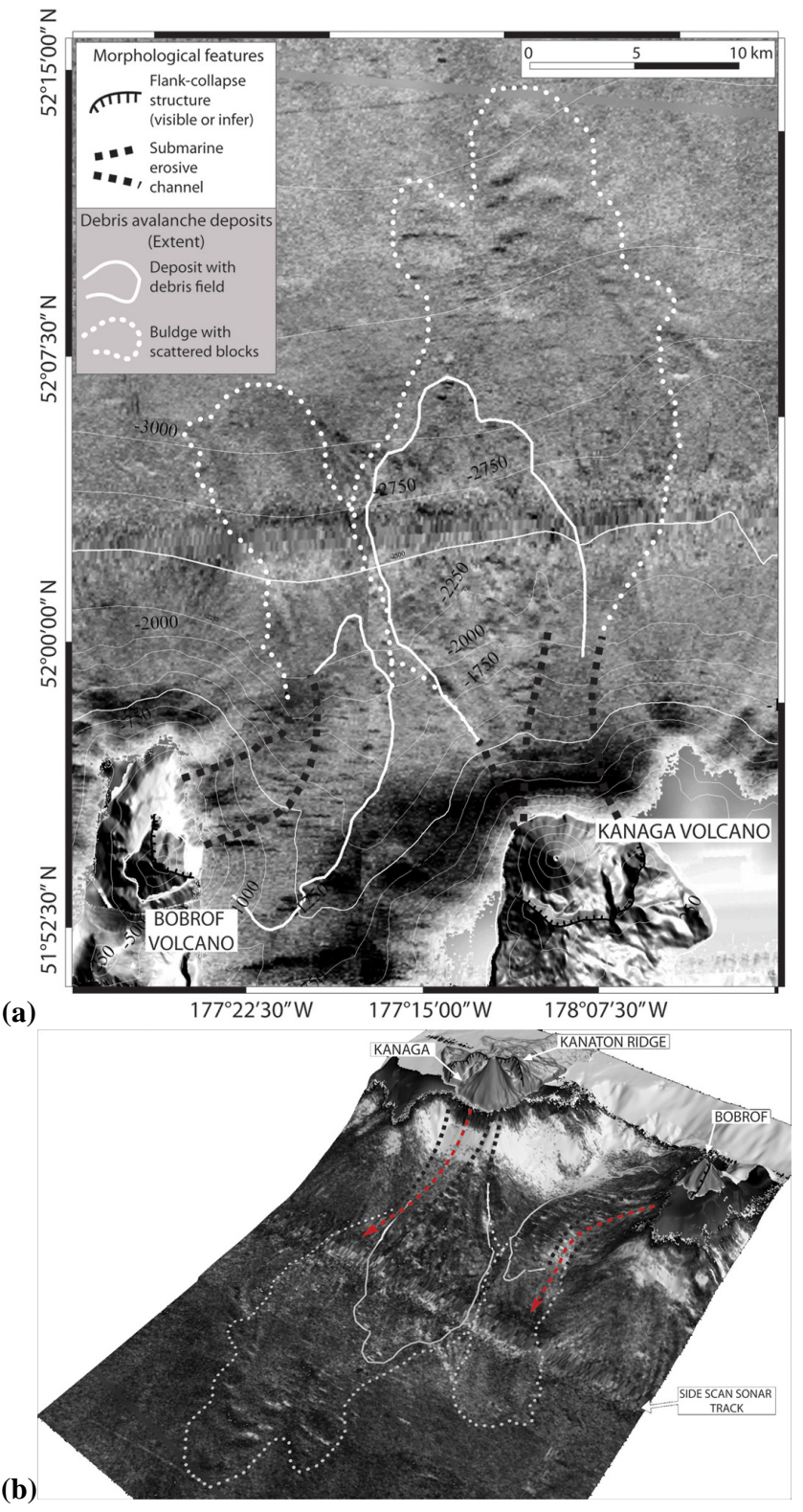

Fig. 8. (a) Plan view: topography, bathymetry and Gloria side-scan data of northern slope of Bobrof and Kanaga islands. The image displays the DA from both the islands; the two active canyons affect the deposits are also showed. Black is high backscatter, white is low backscatter and contour interval is $250 \mathrm{~m}$. (b) 3-D view. Black is low backscatter and white is high backscatter.

DA deposit, covering about $1000 \mathrm{~km}^{2}$, is characterized by blocks oriented in a NNE-direction, and has been partially buried by the younger event.

We propose that this earlier event may have the product of a collapse episode from the "Sandy Bay shield volcano" or perhaps an earlier cycle of the Great Sitkin volcano. Based on the distribution of the older submarine DA deposits, we infer the edifice failure may have occurred from an area

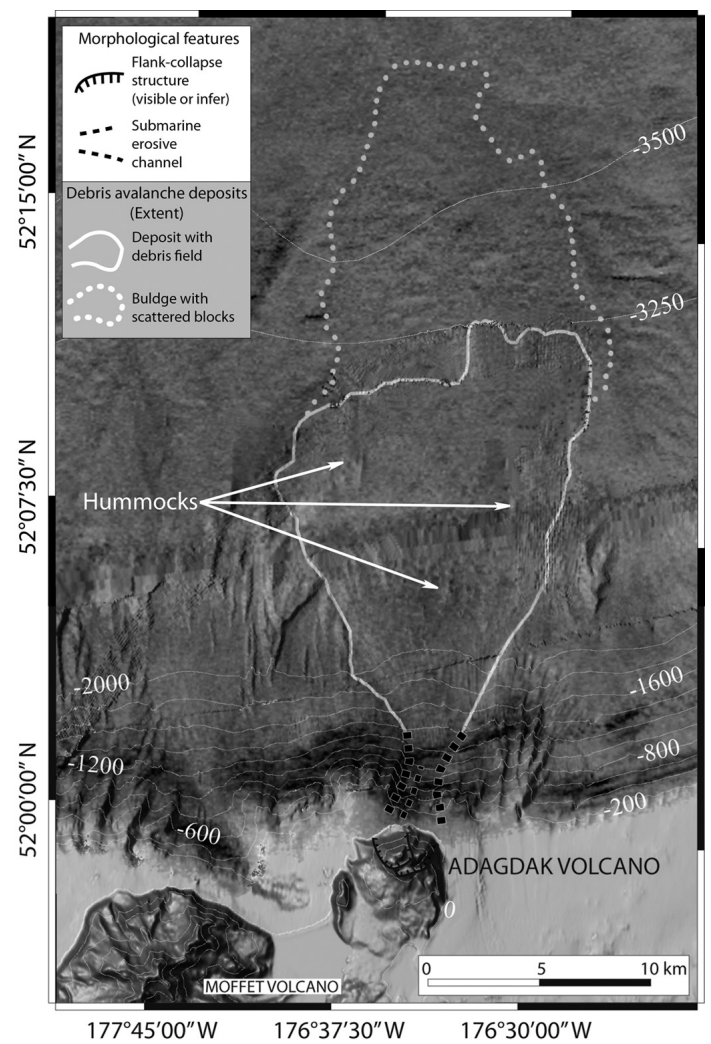

Fig. 9. Topography, bathymetry and Gloria side-scan data of Adagdak volcano and its northern submarine portion. For side scan data the black is high backscatter and white is low backscatter. Contour interval is $200 \mathrm{~m}$.

slightly south of the modern edifice (Fig. 10). The field evidence of this older episode of edifice collapse may have been destroyed by glacial erosion or buried by recent volcanic activity on the subaerial parts of Great Sitkin Island.

Several large channels $(800-1000 \mathrm{~m}$ wide and $4.5 \mathrm{~km}$ long) are cut into the seafloor from the shallow platform down to the slope, suggesting high transportation rates of volcaniclastic sediment from the island to the proximal part of the DA deposits, where the hummocks appear subdued and partially buried.

\subsection{Seguam (Pyre Pk)}

Seguam Island consists of the remnants of two late Quaternary calderas, both with Holocene volcanic cones growing inside of them. A third Holocene cone lies at the east end of the island (Singer et al., 1992; Fig. 11).

Unfortunately, little high resolution data is available from the subsurface around Sequam Island, but the submarine flank to the NW, extending from the eastern caldera breach seaward, is characterized by an irregular, rough-appearing region on GLORIA imagery (Fig. 11).

This area, covering about $250 \mathrm{~km}^{2}$, appears to be a large block field very similar in size and character to those 


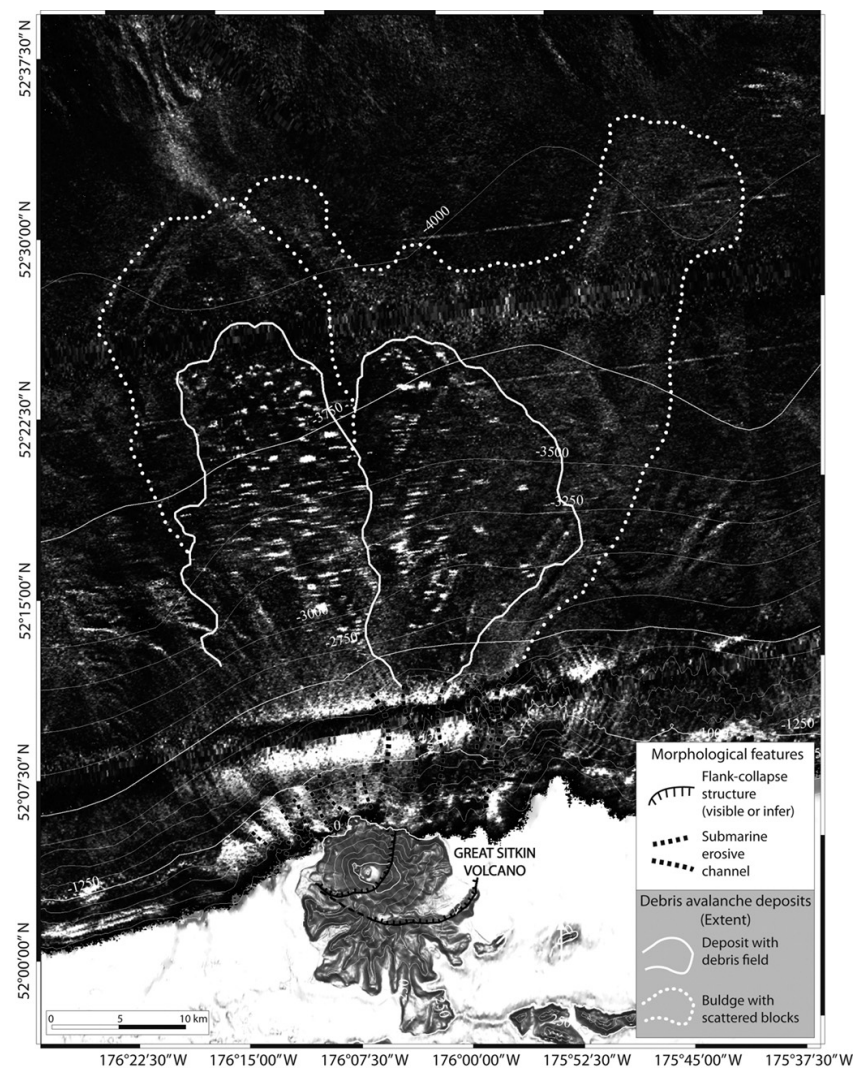

Fig. 10. Topography, bathymetry and Gloria side-scan data of Great Sitkin Volcano and its north submarine flank. The image displays the two inferred deposits characterized by the alignment of the largest blocks of the DA (as reported in the text). For side scan data the black is low backscatter and white is high backscatter. Contour interval is $250 \mathrm{~m}$.

observed offshore from the Garove caldera in the Bismarck arc (Silver et al., 2009); we tentatively consider this highreflectivity region to be a DA deposit representing one or more collapse that may have been connected with the caldera-forming event but further work is necessary to confirm this.

\subsection{Recheschnoi}

Based on our space shuttle laser topographic model, we identified a huge amphitheater scar, probably accentuated by glacial erosion, on the west side of Recheshnoi Volcano (Fig. 12). We suggest that this feature is a scarp produced by a lateral collapse that involved an ancestral Recheshnoi volcano, but while some proximal submarine features appeared to be landslide hummocks and blocks, side-scan sonar imagery and available multibeam data did not allow the delineation of the full size or extent of the submarine DA deposit farther downslope where it entered a large submarine canyon system.

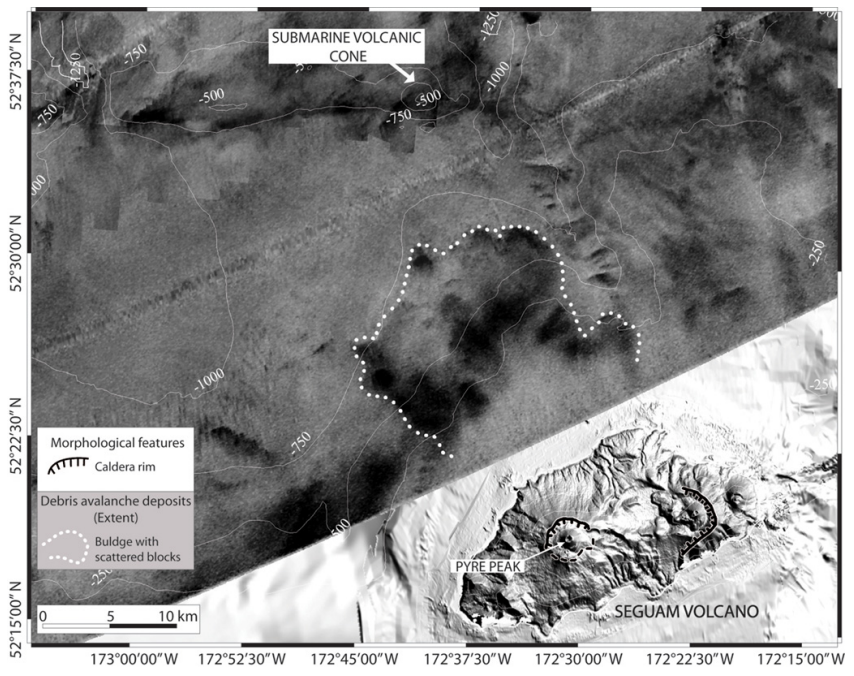

Fig. 11. Topography, bathymetry and Gloria side-scan data of Seguam Island and its northwest submarine part. On the north side a large submarine cone is also visible. For side scan data the black is high backscatter and white is low backscatter. Contour interval is $250 \mathrm{~m}$.

Based on the position and length of the scarp, this may be single largest landslide from any of the Aleutian Islands. Indeed we estimate an original subaerial volume failure of about $30 \mathrm{~km}^{3}$ for this collapse event based a reconstruction of the size of the original volcano from the space shuttle altimetry data (Table 1).

\section{Discussion}

In the course of this study at least 17 flank collapse events have been documented or inferred along the Aleutian Ridge (Table 1).

Two substantially different morphologies are observed in the submarine DA deposits created by flank collapse events along the Aleutian Ridge. The first variety, which we call a "Type I" DA deposit, include large volume DA that are characteristically longer than they are wide, and that typically contain abundant landslide blocks that become less abundant and smaller with distance from the volcano. The second variety tends to be smaller in volume, and typically have a debris field with a lobate shape that is wider then it is long. These "Type II" DA deposits contain many large blocks that occur over the entire surface of the deposit (Table 1).

The morphology of the Type I DA deposits indicate an elevated degree of fragmentation of the blocks that would be accompanied by the generation of abundant fine-grained matrix material that in turn can promote a hydroplaning effect (Mohrig et al., 1998, 1999) and result in long run-outs seen in this type of flow (Table 1). Moreover the hydroplaning effect may be triggered by the higher speeds that characterize larger volume DA events (Ward and Day, 2003). 


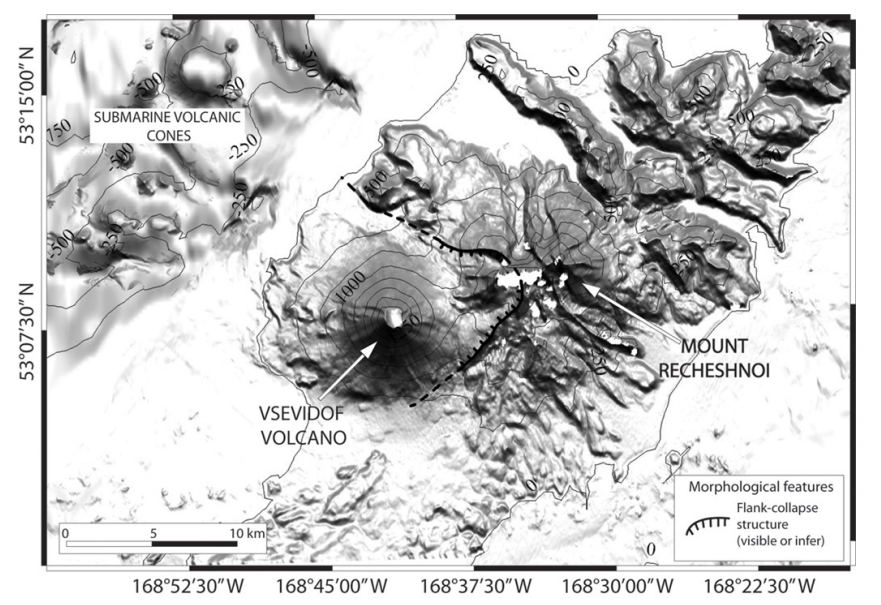

Fig. 12. Position of amphitheatre walls on the SW side of Recheshnoi.

The Type II DA deposits are typically smaller in volume and are characterized by a low degree of fragmentation and appear to contain a higher proportion of large blocks and a lower proportion of fine-grained matrix material then the Type I DA deposits. All these factors would tend to reduce the tendency to "hydroplane" in Type II deposits, and may account for the fact that these landslide masses generally stopped soon after the slope break.

These two types of submarine DA deposits have been described at other island volcanoes, such as the Icod (elongate) and El Golfo (lobate) landslide deposits described from the Canary islands (Masson et al., 2002). The fundamental control on the relative proportion of huge lithic blocks and fine-grained matrix material in these DA deposits is inferred to be the original nature of the volcanic edifice that failed was transformed into landslide debris. The volume and characteristic of the landslide debris then strongly influence the flow processes that act upon the landslide debris to produce downslope movement and the eventual DA deposit. Perhaps the most important factor in controlling flow mobility is the proportion of fine grained material (Masson et al., 2002) which in turn is related to the nature of the failed volcanic edifice. In the Canary Islands some volcanoes consist largely of basalt flows and similar indurate rocks, such as those on El Hierro Island which gave rise to the El Golfo deposit, while other volcanoes include a much greater proportion of pyroclastic material, such as those on Tenerife Island that gave rise to the Icod DA.

Despite the limited knowledge on the geology of the study area and on the islands proportion of lava flows compared to pyroclastic and other deposits, we attempt to explain the distribution of Type I and Type II DA deposits by using the Icod and El Golfo models. Type I DA deposits were generated from Sajaka, Kanaga, Adagdak and Great Sitkin volcanoes, all of which probably consist mostly of lava flows

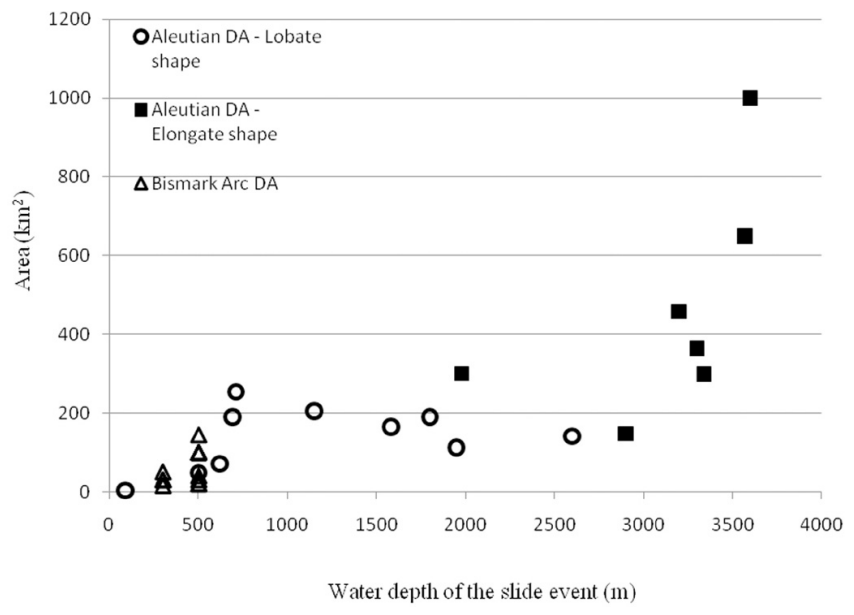

Fig. 13. Depth to distal toe, expressed as water depth of the slide event $(\mathrm{m})$, relative to area covered by DAs $\left(\mathrm{km}^{2}\right)$ from Aleutian Ridge studied cases and from Bismark Arc (Silver et al., 2009). The different trends for the two types of deposits are clearly recognizable.

interbedded with pyroclastic products (Waythomas et al., 2003c; Coombs et al., 2007b), whereas for Little Sitkin and Seguam Volcanoes lobate Type II DA deposits were generated from collapse of a volcanic systems which seems to have produced dominantly lava flows (Snyder, 1959; Singer et al., 1992).

In addition to the primary lithology of the material incorporated in these volcanic landslides, other factors can play important roles in determining the characteristics of the resultant DA deposits. For instance, at Kiska, Segula and Gareloi volcanoes, the depth of emplacement of the DA and the volume of material involved in the landslide event played significant roles in determining the nature of the resultant DA deposit. At these sites lobate Type II deposits are found in shallower water $(<2000 \mathrm{~m}$ b.s.l. versus the $>2500 \mathrm{~m}$ depth most Type I deposits are found in) and the deposits covered a smaller area (Table 1 and Fig. 13). Similar shallow water condition are present in the Bismark Arc and lead to the formation there of DA deposits that almost all show a lobate shape similar to the Type II DA deposits we describe here from the Aleutian Islands. The lobate deposits in the Bismark Islands are relatively smaller, typically covering an area ranging between 15 and $145 \mathrm{~km}^{2}$ and were emplaced at depths between 300-500 m (Silver et al., 2009; Fig. 13). The relatively small volumes and small vertical elevation losses probably minimize the degree of fragmentation in these DAs and tend to result in a Type II landslide deposit of limited mobility.

The general relationships linking landslide volume and long landslide travel distances do not always hold in every case. For instance the Bobrof DA deposit is an exception to the pattern as it has a small surface area but a long run-out; for this event some unusual submarine topography 
apparently was important in controlling mobility. The Bobrof submarine landslide was channeled into a narrow northtrending valley where it encountered the older Kanaga DA deposit (Fig. 8). The width of the Bobrof landslide was limited by the margins of the channel, increasing the depth of the flow and possibly promoting hydroplaning by ingesting and trapping highly pressurized fluids within the channelized flow resulting in increased mobility (Mohrig et al., 1998). A similar small but highly mobile DA is found in the Bismark Arc where the Ritter Island DA extends to about $35 \mathrm{~km}$ from Ritter Island where it is largely confined between the edifices of Umboi and Sakar volcanoes (Silver et al., 2009).

Almost all of the 17 Aleutian Island giant landslide events described in this paper occurred from active volcanic edifices. Of these, at least six collapses probably occurred in the last $100 \mathrm{ka}$. All of these volcanic DAs appear to have originated principally from the subaerial parts of the volcanic edifices except for one landslide at Gareloi volcano that involved removal of substantial sections of the submarine part of the volcanic edifice. In some cases eroded submarine depressions and channels were observed downslope from the subaerial scar; these could represent a secondary submarine slide region that might have been triggered by the same eruption that generated the subaerial landslide, or perhaps an area that was eroded and incorporated into the moving submarine landslide and so contributed large amounts of sediment to the debris field of the DA deposit. The hypothesis that significant amounts of submarine material is being incorporated into the DA deposits is supported by the difference between the volume estimates for the amount of material released from Aleutian volcanoes by subaerial failure and the far larger amounts of material making up the concomitant submarine landslide deposit (Table 1). This "bulking up" of the submarine DA deposits with incorporated sediment is especially significant for the Type I DA deposits, which were as much as three times larger than the original volcanic landslide mass. Still other factors probably played a key a role in triggering the 17 giant volcanic landslides present along the Aleutian Arc and in controlling their size and orientation. The deep-seated failure events that affected the Kiska, Great Sitkin, Kanaga, and Tanaga volcanoes originated when a large part of the edifice collapsed into the sea on the unbuttressed north side of the volcanic massif. These landslides may have been triggered when crustal loading during the growth of these volcanic cones helped produce locally significant slopes to the north. Because most of the active Aleutian arc volcanoes occur on the northern side of Aleutian Islands, the volcanoes tend to be oversteepened to the north and virtually all of the DA deposits are found in the Bering Sea to the north (Coombs et al., 2007b). A similar situation occurs in the southern part of the Antilles arc (Deplus et al., 2001; Boudon et al., 2007) where collapse events tend to mainly affect the western flanks of the volcanoes. We suggest that similar failures affect Segula, Little Sitkin, Adagdak and Recheschnoi Islands.
Another key factor influencing the orientation of large collapse events in the Aleutian arc seems to be the large-scale volcano-tectonic structure of the Aleutian Arc. We found a clear relationship between the orientation of fault systems underlying the Aleutian volcanoes and the opening direction of the amphitheatre scarps left by DAs (Lagmay and Valdivia, 2006) supporting the idea of a tectonic control on the genesis of these deep-seated failure. Most of the Aleutian Volcanoes described here have landslide scarp openings perpendicular to the strike of regional normal fault systems (Francis and Self, 1987; Acocella, 2005) or an angular relationship between the direction of collapse scarp opening and the underlying strike-slip fault (Lagmay and Valdivia, 2006).

Some important differences also exist in the type of landslides produced at Aleutian volcanoes. A thin-skinned failure involving only a small volume of material produced a narrow collapse scar at the Gareloi volcano (Coombs et al., 2007b) but the much larger volume of material in the northwarddirected DA must be due to a deep-seated failure that incorporates much of the interior of the volcano. The large Type I DA deposits from Kiska and Bobrof volcanoes also almost certainly record deep-seated failures.

While little is known about the types of eruptions that might have triggered these volcanic landslides, at least one Bezymianny-type collapse, where the landslide event is accompanied by an explosive magmatic eruption and lateral pyroclastic surge or blast, is known to have occurred on the Sajaka I edifice (Coombs et al., 2007b).

\subsection{Estimates of tsunami hazard from Aleutian volcanoes}

Estimates of the volume of submarine DA deposits can be used to model the size of tsunamis generated by the avalanche. We have estimated the volume of some of the better constrained DA deposits produced by Aleutian volcanoes by integrating estimated thicknesses across the mapped extent of the deposits as obtained using the multibeam data. The average thickness estimates were derived by assuming a transversely lenticular shape for the deposits. We then used the morphology of the adjacent parts of the sea floor that were not buried by DA to infer the geometry of the deposit base, and reconstructed a hypothetical transversal profile of the DA for multiple cross sections. Using this data we then determined an average thickness for different parts of the deposit and estimated a total volume by multiplying this latter value by the area of the deposit (Table 1). Sources of error in these estimates derive mainly from the difficulty in accurately determining the morphology of the part of the sea floor buried by the DA deposits and in not considering a possible inclusion of material ripped from the existing sea-floor.

Estimates were also made of the volumes of the initial landslide debris produce by failures of the subaerial volcanic edifices. These estimates were made by assuming a simple conical morphology existed before the collapse and then 
Table 2. Estimated amplitude of tsunami wave at fixed distance from source for 9 of the studied debris avalanches.

\begin{tabular}{lccccccc}
\hline Volcano DA & $\begin{array}{c}\text { Average thickness } \\
T(\mathrm{~m})\end{array}$ & $\begin{array}{c}H o \\
(\mathrm{~m})\end{array}$ & $\begin{array}{c}\text { Area } \\
\left(\mathrm{km}^{2}\right)\end{array}$ & $\begin{array}{c}A(\mathrm{~m}) \text { at } \\
R=1 \mathrm{~km}\end{array}$ & $\begin{array}{c}A(\mathrm{~m}) \text { at } \\
R=10 \mathrm{~km}\end{array}$ & $\begin{array}{c}A(\mathrm{~m}) \text { at } \\
R=100 \mathrm{~km}\end{array}$ & $\begin{array}{c}A(\mathrm{~m}) \text { at } \\
R=1000 \mathrm{~km}\end{array}$ \\
\hline Great Sitkin DAI & $47^{*}$ & 3600 & 1000 & 44.3 & 29.2 & 6.2 & 0.6 \\
Gareloi DAI & $20^{*}$ & 3200 & 458 & 18.4 & 10.5 & 1.8 & 0.2 \\
Kanaga DA & $70^{*}$ & 3300 & 364 & 63.7 & 34.7 & 5.8 & 0.5 \\
Kiska DA II & 85 & 1980 & 300 & 76.6 & 40 & 6.4 & 0.6 \\
Adagdak DA & 35 & 3340 & 299 & 31.5 & 16.5 & 2.6 & 0.2 \\
Kiska DA I & 45 & 1580 & 165 & 39.2 & 17.8 & 2.5 & 0.2 \\
Bobrof DA & 60 & 2900 & 148 & 51.9 & 22.9 & 3.2 & 0.3 \\
Sajaka I DA & $20 *$ & 2600 & 142 & 17.2 & 7.5 & 1 & 0.1 \\
Gareloi DAIII & 80 & 1950 & 113 & 67.8 & 28 & 3.7 & 0.3 \\
\hline
\end{tabular}

* average thickness obtained dividing the subaerial failure volume by the submarine deposit area

using DEM data to calculate the difference between the modeled pre-collapse volcano and the observed modern volcano and collapse scarp (Table 1).

For some of the better delineated DA deposits (Fig. 14; Table 2) we estimated the potential amplitude $A(R)$ of a tsunami wave at fixed distance $\mathrm{R}$ from the source volcanic landslide using formulas derived from numerical models of landslide tsunamis by Ward and Day (2003):

$A(R)=T \times(1+2 R / D)^{-\phi}$

where

$\phi \quad 0.5+0.57 \mathrm{e}^{(-0.0175 \mathrm{D} / \mathrm{Ho})}$

$T \quad$ Thickness of the unit

$R$ Distance of measurement point from the source

$D \quad(4 \cdot \text { Area } / \pi)^{1 / 2}$

Ho water depth of the slide event

A similar approach was used by Silver et al. (2009) to estimate the magnitude of tsunamis expected from future collapse events in the Bismark Arc.

The numerical models showed that the amplitude of tsunamis produced by landslides into in the sea is very sensitive to water depth $(\mathrm{Ho})$ and directly proportional to deposit thickness, $T$.

Because we base our calculations on estimates of the average thickness of the submarine DA deposits rather than an estimate of maximum thickness at the time of DA emplacement, our calculations of potential tsunami heights are probably underestimations of the actual maximum potential of Aleutian volcanic DAs to generate enormous tsunamis. Despite this conservative approach, the models predict the formation of huge waves that can be initially as much as $100 \mathrm{~m}$ high (Table 2). Such huge tsunami waves would progressively decrease in height as the wave propagated away from the source landslide, but could still be as much as several meters high at distances of several hundred kilometers from the source. When the waves encounter shore the waves can be focused by interactions with the seafloor and coastal geomor-

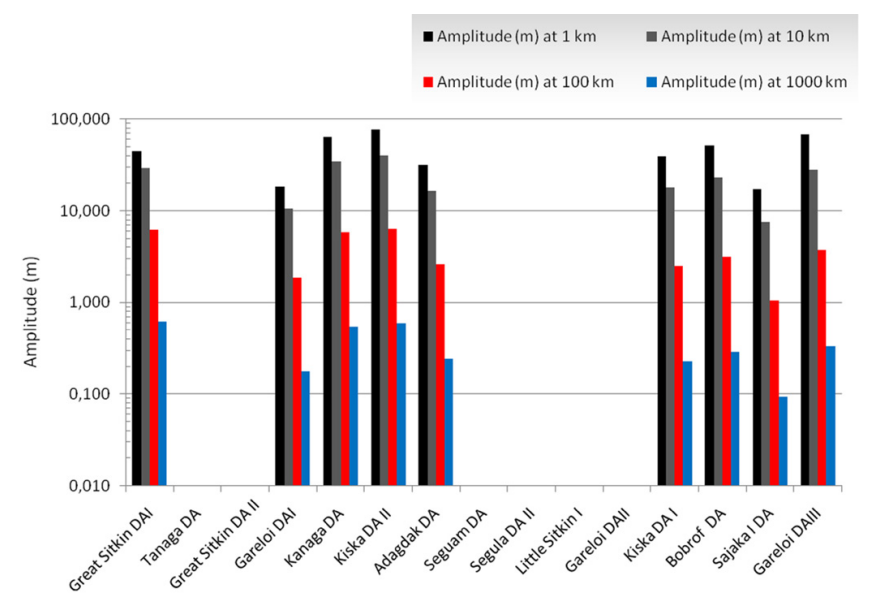

Fig. 14. Histogram showing the estimated amplitude of tsunami wave at fixed distance from the source, for 9 of DAs reported in Table 2 .

phology so that the actual tsunami run-up elevation is typically two or three times greater than the initial wave height.

\section{Conclusions}

The combination of marine bathymetry and terrestrial space shuttle altimetry data sets has allowed us to identify and characterize $17 \mathrm{DA}$ deposits from 11 volcanoes in the central Aleutian arc.

The area covered by these deposits ranges from 4 to $1000 \mathrm{~km}^{2}$. While the ages of the DA deposits cannot be precisely determined, at least six of the collapse events appeared to have occurred in the last $100 \mathrm{ka}$ based on the absence of significant sediment cover.

If a collapse event similar to those that generated the largest of the prehistoric Aleutian DA deposits described here were to occur now, it would generate a significant tsunami that that might be initially as much as $100 \mathrm{~m}$ high. Such an 
event would almost certainly destroy nearby coastal communities and infrastructure in the Aleutian Islands, and might affect some sites at considerable distances from the source volcano.

Landslide tsunamis often propagate most efficiently in the same direction as the original landslide, so there might be tremendous variation is the far field effects of such tsunamis, with some areas hundreds or even thousands of kilometers away still being at risk of inundation. Because of the northfacing aspect of the Aleutian Volcanoes, the far-field tsunami hazard is probably greater for communities around the margins of the Bering then for communities lying south of the Aleutian Arc.

While catastrophic collapse events that produce tsunamis at island volcanoes occur much less frequently then tsunami generation due to seismic events, their destructive impacts may be larger. For that reason, we urge that additional studies be made of the geology and geophysics of the Aleutian Islands and their volcanoes, and that further marine geophysical surveys be done around the volcanoes to collect multibeam and seismic data, and that direct sampling and detailed mapping be carried out on these recently recognized DA deposits to obtain additional information necessary to better understand their volcanology, geomorphology, edifice collapse processes, tsunami generation and propagation processes and other factors that can help evaluate the magnitude of the hazard from the Aleutian Islands and guide tsunami modelling.

Acknowledgements. This work is a result of a project funded by a grant of the "Sapienza" University of Rome, Italy. Thanks to: Jennifer Reynolds, Jessica Larsen, Zygmunt Kowalik, Francesco Latino Chiocci, Daniele Casalbore and Bernard Coakley for suggestions and critical review on this work. Also thanks to Nancy Bigelow, Sarah Henton, Mary Keskinen, Silvio de Angelis, Maciej G. Sliwinski, David McAlpine, Jason Addison and the UAF Geology department people. We offer special thanks to Michelle Coombs of the US Geological Survey and Lee Siebert of the Smithsonian Institution who helped this work with their constructive manuscript reviews and gracious discussions of many aspects of debris avalanche.

Edited by: J. Marti

Reviewed by: L. Siebert and M. Coombs

\section{References}

Acocella, V.: Modes of sector collapse of volcanic cones: Insights from analogue experiments, J. Geophys. Res., 110, B02205, doi:10.1029/2004JB003166, 2005.

Beget, J.: Volcanic Tsunamis, in: Encyclopedia of Volcanoes, edited by: Sigurdsson, H., Academic Press, San Diego, CA, pp. 431-445, 2000.

Beget, J. and Kienle, J.: Cyclic formation of debris avalanches at Mount St. Augustine Volcano, Alaska, Nature, 356, 701-704, 1992.

Beget, J. E. and Waitt, R. B.: Volcanic processes and geology of Augustine Volcano, Alaska: US Geol. Surv. Prof. Pap., 1762, 78 p., 2 plates, scale 1:25,000, available at http://pubs.usgs.gov/pp/ 1762/, 2009.

Beget, J., Gardner, C., and Davis, K.: Volcanic tsunamis and prehistorical cultural transitions in Cook Inlet, Alaska, J. Volcanol. Geotherm. Res., 176, 377-386, 2008.

Boudon, G., Le Friant, A., Komorowski, J. C., Deplus, C., and Semet, M. P.: Volcano flank instabilities in the Lesser Antilles arc: diversity of scales, processes and temporal recurrence, J. Geophys. Res., 112, B08205, doi:10.1029/2006JB0004674, 2007.

Canals, M., Lastras, G., Urgeles, R., Casamor, J. L., Mienert, J., Cattaneo, A., De Batist, M., Haflidason, H., Imbo, Y., Laberg, J. S., Locat, J., Long, D., Longva, O., Masson, D. G., Sultan, N., Trincardi, F., and Bryn, P.: Slope failure dynamics and impacts from seafloor and shallow sub-seafloor geophysical data: case studies from the COSTA project, Mar. Geol., 213(1-4), 97, 2004.

Clouard, V., Bonneville, A., and Gillot, P. Y.: A giant landslide on the southern flank of Tahiti Island, French Polynesia, Geophys. Res. Lett., 28, 2253-2256, 2001.

Coats, R. R.: Geology of northern Adak Island, Alaska, in: Investigations of Alaskan volcanoes, US Geol. Surv. Bull., B 1028-C, 45-67, 1956a.

Coats, R. R.: Geology of northern Kanaga Island, Alaska, US Geol. Surv. Bull. 1028-D, 69-81, 1956 b.

Coats, R. R.: Geologic reconnaissance of Gareloi Island, Aleutian Islands, Alaska, US Geol. Surv. Bull. 1028-J, 249-256, 1959c.

Coats, R. R., Powers, H. A., Nelson, W. H., and Lewis, R. G.: Geologic reconnaissance of Kiska Island, Aleutian Islands, Alaska, US Geol. Surv. Bull. 1028-B, 563-581, 1961.

Coombs, M. L., McGimsey, R. G., and Browne, B. L.: Preliminary volcano-hazard assessment for the Tanaga Volcanic Cluster, Tanaga Island, Alaska, US Geol. Surv. Scientific Investigations Report, 2007-5094, 36 p., 2007a.

Coombs, M. L., White, S. M., and Scholl, D. W.: Massive edifice failure at Aleutian arc volcanoes, Earth Planet. Sci. Lett., 256, 403-418, doi:10.1016/j.epsl.2007.01.030, 2007b.

Coombs, M. L., McGimsey, R. G., and Browne, B. L.: Preliminary volcano-hazard assessment for Gareloi Volcano, Gareloi Island, Alaska, US Geol. Surv. Investigations Report 2008-5159, 29 p., 2008.

DeLong, S. E., Fox, P. J., and McDowell, F. W.: Subduction of the Kula Ridge at the Aleutian Trench. Geol. Soc. Am. Bull., 89, 83-95, 1978.

Deplus, C., Le Friant, A., Boudon, G., Komorowski, J.-C., Villemant, B., Harford, C., Se'goufin, J., and Cheminée, J.-L.: Submarine evidence for large scale debris avalanches in the Lesser Antilles Arc, Earth Planet. Sci. Lett., 192, 145-157, 2001.

Eakins, B. W. and Robinson, J. E.: Submarine geology of Hana Ridge and Haleakala Volcano's northeast flank, Mauai, J. Volcanol. Geotherm. Res., 151, 229-250, 2006.

Engebretson, D. C., Cox, A., and Gordon, R. G.: Relative motions between oceanic and continental plates in the Pacific Basin, Geol. Soc. Am. Spec. Pap., 206, 1-59, 1985.

Exclusive Economic Zone Staff: Atlas of the U.S. Exclusive Economic Zone, Bering Sea, US Geological Survey Miscellaneous Investigations Series Map I-2053, 1991.

Farr, T. G., Rosen, P. A., Caro, E., Crippen, R., Duren, R., Hensley, S., Kobrick, M., Paller, M., Rodriguez, E., Roth, L., Seal, D., 
Shaffer, S., Shimada, J., Umland, J., Werner, M., Oskin, M., Burbank, D., and Alsdorf, D.: The Shuttle Radar Topography Mission, Rev. Geophys., 45, RG2004, doi:10.1029/2005RG000183, 2007

Francis, P. W. and Self, S.: Collapsing volcanoes, Sci. Am., 255, 90-97, 1987.

Geist, E. L., Childs, J. R., and Scholl, D. W.: The origin of summit basins of the Aleutian Ridge: implications for block rotation of an arc massif, Tectonics, 7, 327-341, 1988.

Groome, M. G., Gutmacher, C. E., and Stevenson, A. J.: Atlas of GLORIA Sidescan-Sonar Imagery of the Exclusive Economic Zone of the United States: EEZ-View, US Geological Survey Open-File Report 97-540, 1 CD-ROM, 1997.

Grow, J. A. and Atwater, T.: Mid-Tertiary tectonic transition in the Aleutian Arc, Geol. Soc. Am. Bull., 81, 3715-3722, 1970.

Holcomb, R. T. and Searle, R. C.: Large landslides from oceanic volcanoes, Mar. Geotechnol., 10, 19-32, 1991.

Jicha, B. R., Scholl, D. W., Singer, B. S., Yogodzinski, G. M., and Kay, S. M.: Revised age of Aleutian Island Arc formation implies high rate of magma production, Geology, 34, 661-664, 2006.

Karl, H. A., Carlson, P. R., and Gardner, J. V.: Aleutian Basin of the Bering Sea: Styles of sedimentation and canyon development, in: Geology of the United States' seafloor: The view from GLORIA, edited by: Gardner, J. V., Field, M. E., and Twichell, D. C., Cambridge University Press, Cambridge, xii, 364 pp., ISBN 0-521-43310, 1996.

Kay, S. M., Kay, R. W., and Citron, G. P.: Tectonic controls on tholeiitic and calc-alkaline magmatism in the Aleutian Arc, J. Geophys. Res., 87, 4051-4072, 1982.

Lagmay, A. M. F. and Valdivia, W.: Regional Stress Influence on the opening direction of craters in Southeast Asian volcanoes, J. Volcanol. Geotherm. Res., 158(1-2), 139-150, doi:10.1016/j.jvolgeores.2006.04.020, 2006.

Le Bas, T. P., Masson, D. G., Holtom, R. T., and Grevemeyer, I.: Slope failures of the flanks of the southern Cape Verde Islands, in: Submarine mass movements and their consequences, edited by: Lykousis, V., Sakellariou, D., and Locat, J., 3rd International Symposium, Dordrecht, Netherlands, Springer, 337-345, 2007.

Marlow, M. S., Scholl, D. W., Buffington, E. C., and Alpha, T. R.: Tectonic history of the central Aleutian Arc, Geol. Soc. Amer. Bull., 84, 1555-1574, 1973.

Masson, D. G., Watts, A. B., Gee, M. J. R., Urgeles, R., Mitchell, N. C., Le Bas, T. P., and Canals, M.: Slope failures on the flanks of the western Canary Islands, Earth Sci. Rev., 57(1-2), 1-35, 2002

Masson, D. G., Le Bas, T. P., Grevemeyer, I., and Weinrebe, W.: Flank collapse and large-scale landsliding in the Cape Verde Islands, off West Africa, Geochem. Geophys. Geosyst., 9, Q07015, doi:10.1029/2008GC001983, 2008.

Miller, T. P., McGimsey, R. G., Richter, D. H., Riehle, J. R., Nye, C. J., Yount, M. E., and Dumoulin, J. A.: Catalog of the historically active volcanoes of Alaska, US Geological Survey Open-File Report 98-0582, 104 pp., 1998.

Mohrig, D., Whipple, K. X., Hondzo, M., Ellis, C., and Parker, G.: Hydroplaning of subaqueous debris flows, Geol. Soc. Am. Bull., 110, 387-394, 1998.

Mohrig, D., Elverhøi, A., and Parker, G.: Experiments on the relative mobility of muddy subaqueous and subaerial debris flows, and their capacity to remobilize antecedent deposits, Mar. Geol., 154, 117-129, 1999.

Moore, J. G., Clague, D. A., Holcomb, R. T., Lipman, P. W., Normark, W. R., and Torresan, M. E.: Prodigious submarine landslides on the Hawaiian Ridge, J. Geophys. Res., 94, 1746517484, 1989.

Moore, J. G., Normark, W. R., and Holcomb, R. T.: Giant Hawaiian landslides. Annu. Rev. Earth Planet. Sci., 22(1), 119-144, doi:10.1146/annurev.ea.22.050194.001003, 1994.

NOAA's National Geophysical Data Center (NGDC): http://www. ngdc.noaa.gov/, access: September 2009.

Nelson, W. H.: Geology of Segula, Davidof and Khvostof Islands, Alaska: in Investigations of Alaskan volcanoes, US Geol. Surv. Bull., B 1028-K, 257-266, 1959.

Reynolds, J. R., Greene, G., Krutikov, L., and Vallier, T. L.: Submarine volcanic cones in the central Aleutian arc: relationship to arc rifting and oblique convergence, Eos, Trans. - Am. Geophys. Union, 85, Abstract T41C-1230, 2004.

Romagnoli, C., Casalbore, D., Chiocci, F. L., and Bosman, A.: Offshore evidence of large-scale lateral collapse on the eastern flank of Stromboli, Italy, due to structurally-controlled, bi-lateral flank instability, Mar Geol., 262, 1-13, 2009.

Satake, K. and Kato, Y.: The 1741 Oshima-Oshima eruption: extent and volume of submarine debris avalanche, Geophys. Res. Lett., 28, 427-430, 2001.

Schaefer, J. and Nye, C. J.: Historically active volcanoes of the Aleutian Arc: Alaska Division of Geological and Geophysical Surveys Miscellaneous Publication MP 0123, unpaged, 1 sheet, scale 1:3000 000, 2002.

Silver, E., Day, S., Ward, S., Hoffmann, G., Llanes, P., Driscoll, N., Applegate, B., and Saunders, S.: Volcano collapse and tsunami generation in the Bismarck Volcanic Arc, Papua New Guinea, J. Volcanol. Geotherm. Res., 186, 210-222, doi:10.1016/j.jvolgeores.2009.06.013. 2009.

Simkin, T. and Siebert, L.: Volcanoes of the World (2nd edition), Tucson: Geoscience Press, 369 pp., 1994.

Simons, F. S. and Mathewson, D. E.: Geology of Great Sitkin Island, Alaska, US Geol. Surv. Bull., 1028-B, 21-42, 1955.

Singer, B. S., Myers J. D., and Frost, C. D.: Mid-Pleistocene lavas from the Seguam Island volcanic center, central Aleutian arc: closed-system fractional crystallization of a basalt to rhyodacite eruptive suite, Contrib. Mineral. Petrol., 110, 87-112, 1992.

Snyder, G. L.: Ocean floor structures, northeastern Rat Islands, Alaska: US Geol. Surv. Bull., 1028-6, 161-167, 1957.

Snyder, G. L.: Geology of Little Sitkin Island, Alaska: in Investigations of Alaskan volcanoes, US Geol. Surv. Bull., B 1028-H, 169-210, 1959.

Tibaldi, A.: Multiple sector collapses at Stromboli volcano, Italy: how they work, Bull. Volcanol., 63, 112-125, 2001.

USGS Seamless Data Distribution System: http://seamless.usgs. gov/, access September 2009.

Voight, B., Glicken, H., Janda, R., and Douglas, P.: Catastrophic rockslide avalanche of May 18, in: The 1980 Eruptions of Mount St. Helens, Washington, edited by: Lipman, P. and Mullineaux, D., US Geol. Surv. Prof. Pap., 125, 347-377, 1981.

Ward, S. N. and Day, S. J.: Ritter Island volcano - lateral collapse and the tsunami of 1888, Geophys. J. Int., 154, 891-902, 2003.

Watts, A. B. and Masson, D. G.: A giant landslide on the north flank of Tenerife, Canary Islands, J. Geophys. Res., 100, 24487 
24498, 1995.

Waythomas, C. F., Miller, T. P., and Nye, C. J.: Preliminary Volcano-Hazard Assessment for Kanaga Volcano, Alaska, US Geol. Surv. Open-File Report 02-397, p. 27, 2002.

Waythomas, C. F., Miller, T. P., and Nye, C. J.: Geology and late Quaternary eruptive history of Kanaga Volcano, a calc-alkaline stratovolcano in the western Aleutian Islands, Alaska, US Geol. Surv. Prof. Pap., 1678, 181-197, 2003a.

Waythomas, C. F., Miller, T. P., and Nye, C. J.: Preliminary geologic map of Great Sitkin Volcano, Alaska, US Geol. Surv. OpenFile Report 03-0036, unpaged, 2003b.
Waythomas, C. F., Miller, T. P., and Nye, C. J.: Preliminary volcano hazard assessment for Great Sitkin Volcano, Alaska, US Geol. Surv. Open-File Report 03-0112, 25 pp., 2003c.

Wood, C. A. and Kienle, J.: Volcanoes of North America: United States and Canada, Cambridge University Press (Cambridge), 354 p., ISBN 10: 0521364698, 1991.

Wright, I. C., Worthington, T. J., and Gamble, J. A.: New multibeam mapping and geochemistry of the $30 \mathrm{deg}-35 \mathrm{deg} \mathrm{S}$ sector, and overview, of southern Kermadec arc volcanism, J. Volc. Geotherm. Res., 149, 263-296, 2006. 